\title{
Effects of Cattle Grazing on Mule Deer Diet and Area
} Selection

\author{
DENNIS D. AUSTIN AND PHILIP J. URNESS
}

\begin{abstract}
Split enclosures, half grazed and half ungrazed by cattle in summer, were compared for mule deer habitat use in late summer using tame deer. Diet composition, dietary nutrition, and area selected for grazing by mule deer were used as criteria to assess the grazing effects of cattle. Generally few dietary or nutritional differences were determined. Nonetheless, deer preferred to forage on areas ungrazed by livestock at low deer use levels, but this preference rapidly decreased as deer use increased.
\end{abstract}

Many reported studies have indicated proper livestock grazing maintains or improves habitat for mule deer (Odocoileus hemionus)(Smith 1949, Smith and Doell 1968, Jensen et al. 1972, Longhurst et al. 1979, Smith et al. 1979, Neal 1981, Urness 1981, Reiner and Urness 1982, and others). In such management situations short-term direct effects-primarily competition for forage and habitat - may adversely affect mule deer. Although many studies have dealt with dietary overlap between livestock and mule deer (Hansen and Reid 1975, Hubbard and Hansen 1976, Hansen et al. 1977, Vavra and Sneva 1978, Campbell and Johnson 1983, and others), few have determined changes in mule deer foraging behavior and quantified the results.

Previous study in this area (Austin and Urness 1985) determined forage production and plant variety were abundant in spring and early summer, and that forage selection by mule deer only became potentially restricted in late summer. Therefore the effects of livestock grazing on mule deer would also be expected to be most critical in late summer. Consequently it was the intent of this study to compare late summer diet and area preferences of mule deer on contiguous areas grazed and ungrazed by cattle.

\section{Study Area}

The study site was located in the Sheeprock Mountains of western Utah at 2,100 m elevation (Fig. 1). Precipitation averaged about $35 \mathrm{~cm}$, received mostly as snow in winter. Typical of the scattered, north-south trending ranges within the Great Basin, the Sheeprock Mountains provide limited summer range, primarily comprised of broadleaved shrub communities which are the most extensive and important communities used by mule deer in this area.

The study site, comprised of mixed-browse communities, was managed by the U.S. Forest Service with a 3-pasture rest-rotation grazing system. During summer 1983, a grazing intensity of about $4.4 \mathrm{ha} / \mathrm{AUM}$ of cattle use was applied in the study area.

\footnotetext{
Authors are wildlife biologist and associate professor, Department of Range Science, UMC 52, Utah State University, Logan 84322.

This paper is a contribution of Utah State Division of Wildlife Resources, Federal Aid Project W-105-R.

Manuscript accepted 28 May 1985
}

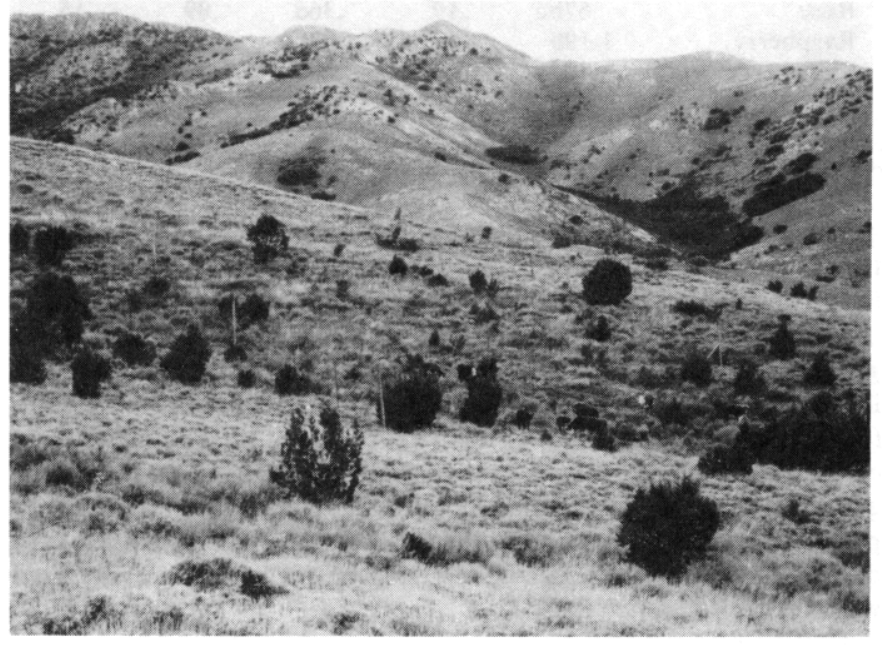

Fig. 1. Limited summer range, containing a diversity of plant communities, received heavy cattle use in the mixed browse vegetation of enclosure $\# 1$.

\section{Methods}

In spring 1983, prior to cattle use, four 0.2 ha sampling areas were established along $1.5 \mathrm{~km}$ of an east slope canyon. Half of each area, selected by coin toss, was fenced to $1.2 \mathrm{~m}$ height to exclude cattle. Use by wild deer continued throughout the summer, but the degree of use was not determined. Following the 1983 prescribed cattle grazing period ending in mid-August, the sampling areas were fenced to a height of $2.5 \mathrm{~m}$, and the center dividing fence from each enclosure was removed (Austin et al. 1983).

Available forage production on each half of each enclosure was determined in August from 100 microplots $(20 \times 50 \mathrm{~cm})$. The design consisted of 20 microplots spaced at meter intervals, along 5 evenly separated, parallel transects, established between opposite fence lines. Production of current annual growth was determined using weight-estimate by species with 1 in every 7 plots randomly selected, clipped, and forage weighed as a check for field estimates. Estimates were converted to an oven-dry basis via clipped samples.

Four tame mule deer, 3 adult bucks and 1 adult doe, were used to determine dietary and habitat choices in each enclosure. Deer were kept within a fifth enclosure to become acclimated to the available forage and area for 10 days prior to the first trial. In each enclosure 
forage selection data were collected first, followed by area selection data. Dietary data were collected by leading individual deer into the enclosure, and then allowing the deer to graze freely until a minimum of 1,400 bites had been recorded. Bites taken on cattlegrazed and -ungrazed areas were recorded separately. After this first grazing period, all 4 deer were placed within the enclosure until an initial tame deer grazing pressure of about 20 deer-days/ha had been accumulated. During this period individual deer were observed on the grazed and/or ungrazed area to increase the number of bites. A minimum of 1,000 bites were collected on each half enclosure for each deer. Bites were converted to oven-dry weight via hand-plucked simulated bites (Neff 1974).

Selection for grazed and ungrazed treatments for foraging was determined by placing all 4 deer together in each enclosure for 24 hours. Scan sampling (Altmann 1974) at 4-minute intervals during the 14 daylight hours (6:32 a.m. to 8:28 p.m.) on 2 separate days was used. By the end of the first day about 40 deer-days/ha (includes initial grazing pressure) were accumulated, with about 60 deer-days/ ha at the end of the trial. Foraging activity was recorded only during those instances when deer were selecting forage.

Following cattle grazing, but prior to the deer foraging trials, plant samples, based on observation of plant parts selected by deer during the acclimatization period, were collected from the grazed and ungrazed treatments. Percent crude protein (CP) and in vitro dry matter digestibility (IVDMD), using rumen inocula from elk fed alfalfa hay (Welch 1983, Brooks and Urness 1984) were determined from standard methods for species comprising $1 \%$ or more of mean diets from each enclosure treatment. All samples were run using a single inocula source with duplicates simultaneously. Dietary percent $C P$ and IVDMD were weighted based on diet composition from individual deer.

\section{Results}

Grass production was generally uniform within the enclosures and since grass typically comprises a high proportion of cattle diets when available, the difference in available production between grazed and ungrazed areas was considered the major criterion defining the degree of cattle grazing. Most forbs were utilized by cattle at about the same degree as were grasses (Table 1); however, because forbs were distributed less evenly, particularly with respect to individual species, they were not used to assess cattle impacts. Total forage within browsing reach of mule deer on the areas ungrazed by cattle averaged $1,369 \mathrm{~kg} /$ ha with $294 \mathrm{~kg} /$ ha grass production; cattle use of grass averaged $66 \%$.

Within enclosure 1 cattle removed about $76 \%$ of the available grass (Fig. 1). Use of palatable browse species, Utah serviceberry (Amelanchier utahensis Koehne) and mountain snowberry (Symphoricarpos oreophilus Gray), was visually apparent and sup-

Table 1. Available vegetal production (dry weight $\mathrm{kg} / \mathrm{ha}$ ) and mule deer diet composition (\% dry weight \pm SEm) of species comprising $1 \%$ or more of mule deer diets on split enclosures-half grazed and half ungrazed by cattle.

\begin{tabular}{|c|c|c|c|c|c|c|c|c|c|}
\hline \multicolumn{5}{|c|}{ Enclosure \#1 } & \multicolumn{5}{|c|}{ Enclosure \#2 } \\
\hline \multirow[b]{2}{*}{ Species } & \multicolumn{2}{|c|}{ Available production } & \multicolumn{2}{|c|}{ Diet composition } & \multirow[b]{2}{*}{ Species } & \multicolumn{2}{|c|}{ Available production } & \multicolumn{2}{|c|}{ Diet composition } \\
\hline & Grazed & $\overline{\text { ungrazed }}$ & Grazed & Ungrazed & & Grazed & Ungrazed & Grazed & Ungrazed \\
\hline $\begin{array}{l}\text { Amelanchier utahensis } \\
\text { Artemisia arbuscula } \\
\text { Symphoricarpos oreophilus } \\
7 \text { other browse species } \\
\text { Total browse } \\
\text { Antennaria spp. } \\
\text { Commandra umbellata } \\
\text { Eriogonum rasemosum } \\
\text { Eriogonum umbellatum } \\
\text { Gayophytum spp. } \\
\text { Linum lewisii } \\
\text { Lithosperma ruderale } \\
\text { Polygonum douglasii } \\
\text { Solidago sparsiflora } \\
10 \text { other forb species } \\
\text { Total forbs } \\
\text { Total grasses } \\
\text { TOTAL }\end{array}$ & $\begin{array}{r}3 \\
137 \\
70 \\
390 \\
600 \\
3 \\
5 \\
2 \\
6 \\
T^{*} \\
2 \\
T \\
2 \\
T \\
11 \\
31 \\
75 \\
706\end{array}$ & $\begin{array}{r}75 \\
86 \\
206 \\
433 \\
800 \\
1 \\
38 \\
6 \\
5 \\
T \\
3 \\
T \\
6 \\
T \\
92 \\
151 \\
313 \\
1264\end{array}$ & $\begin{array}{c}31 \pm 8 \\
2 \pm 1 \\
23 \pm 6 \\
\mathrm{I} \\
56 \pm 3 \quad * * \\
5 \pm 2 \\
2 \pm 1 \\
T \\
1 \pm T \\
2 \pm 1 \\
2 \pm 1 \\
0 \\
22 \pm 3 \\
0 \\
1 \pm 1 \\
35 \pm 2 \quad * * \\
9 \pm 5 \\
100\end{array}$ & $\begin{array}{l}18 \pm 5 \\
T \\
17 \pm 4 \\
T \\
35 \pm 5 \\
T \\
15 \pm 6 \\
5 \pm 2 \\
2 \pm 1 \\
T \\
1 \pm 1 \\
1 \pm 1 \\
35 \pm 6 \\
2 \pm 1 \\
1 \pm 1 \\
62 \pm 5 \\
3 \pm 1 \\
100\end{array}$ & $\begin{array}{l}\text { Amelanchier utahensis } \\
\text { Rosa woodsi } \\
\text { Symphoricarpos oreophilus } \\
8 \text { other browse species } \\
\text { Total browse } \\
\text { Commandra umbellata } \\
\text { Eriogonum racemosum } \\
\text { Eriogonum umbellatum } \\
\text { Linum lewisii } \\
\text { Lithospermum ruderale } \\
\text { Lupinus caudatus } \\
\text { Polygonum douglasit } \\
\text { Solidago sparsiflora } \\
9 \text { other forb species } \\
\text { Total forbs } \\
\text { Total grasses } \\
\text { TOTAL }\end{array}$ & $\begin{array}{r}24 \\
3 \\
367 \\
1156 \\
1550 \\
13 \\
1 \\
3 \\
7 \\
2 \\
167 \\
1 \\
4 \\
11 \\
202 \\
151 \\
1903\end{array}$ & $\begin{array}{r}13 \\
6 \\
282 \\
617 \\
918 \\
27 \\
4 \\
3 \\
2 \\
T \\
106 \\
4 \\
8 \\
54 \\
208 \\
376 \\
1502\end{array}$ & $\begin{array}{l}11 \pm 4 \\
5 \pm 1 \\
36 \pm 9 \\
T \\
52 \pm 10 \\
3 \pm 1 \\
3 \pm 1 \\
1 \pm T \\
T \\
10 \pm 4 \\
3 \pm 2 \\
1 \pm 1 \\
14 \pm 5 \\
1 \pm 1 \\
36 \pm 10 \\
12 \pm 3 \\
100\end{array}$ & $\begin{array}{l}14 \pm 3 \\
2 \pm 1 \\
25 \pm 11 \\
T \\
41 \pm 12 \\
8 \pm 2 \\
2 \pm 1 \\
T \\
5 \pm 2 \\
7 \pm 4 \\
3 \pm 1 \\
20 \pm 4 \\
10 \pm 4 \\
1 \pm 1 \\
56 \pm 11 \\
3 \pm 1 \\
100\end{array}$ \\
\hline \multicolumn{5}{|c|}{ Enclosure \#3 } & \multicolumn{5}{|c|}{ Enclosure \#4 } \\
\hline & \multicolumn{2}{|c|}{ Available production } & \multicolumn{2}{|c|}{ Diet composition } & & \multicolumn{2}{|c|}{ Available production } & \multicolumn{2}{|c|}{ Diet composition } \\
\hline Species & Grazed & ungrazed & Grazed & Ungrazed & Species & Grazed & Ungrazed & Grazed & Ungrazed \\
\hline $\begin{array}{l}\text { Amelanchier utahensis } \\
\text { Quercus gambelii } \\
\text { Symporicarpos oreophilus } \\
3 \text { other browse species } \\
\text { Total browse } \\
\text { Eriogonum racemosum } \\
\text { Lupinus caudatus } \\
\text { Polygonum douglasii } \\
\text { Solidago sparsiflora } \\
\text { Wyethia amplexicaulus } \\
\text { Il other forb species } \\
\text { Total forbs } \\
\text { Total grasses } \\
\text { TOTAL }\end{array}$ & $\begin{array}{r}6 \\
284 \\
210 \\
129 \\
629 \\
1 \\
91 \\
T \\
T \\
T \\
12 \\
104 \\
173 \\
906\end{array}$ & $\begin{array}{r}9 \\
282 \\
207 \\
95 \\
593 \\
4 \\
317 \\
2 \\
52 \\
4 \\
75 \\
454 \\
312 \\
1359\end{array}$ & $\begin{array}{c}23 \pm 12 \\
49 \pm 12 \\
16 \pm 4 \\
0 \\
88 \pm 2 \\
T \\
4 \pm 2 \\
T \\
T * * \\
0 \\
1 \pm 1 \\
5 \pm 2 \\
7 \pm 3 \\
100\end{array}$ & $\begin{array}{c}25 \pm 13 \\
39 \pm 6 \\
10 \pm 4 \\
T \\
74 \pm 7 \\
1 \pm 1 \\
2 \pm 1 \\
3 \pm 1 \\
15 \pm 4 \\
2 \pm 1 \\
1 \pm 1 \\
24 \pm 7 \\
2 \pm 1 \\
100\end{array}$ & $\begin{array}{l}\text { Amelanchier utahensis } \\
\text { Populus tremuloides } \\
\text { Quercus gambelii } \\
\text { Rosa woodsii } \\
\text { Symphoricarpos oreophilus } \\
2 \text { other browse species } \\
\text { Total browse } \\
\text { Chenopodium album } \\
\text { Taraxacum officinale } \\
17 \text { other forb species } \\
\text { Total forbs } \\
\text { Total grasses } \\
\text { TOTAL }\end{array}$ & $\begin{array}{r}12 \\
50 \\
300 \\
14 \\
635 \\
418 \\
1429 \\
T \\
5 \\
14 \\
19 \\
28 \\
1476\end{array}$ & $\begin{array}{r}18 \\
22 \\
111 \\
16 \\
758 \\
205 \\
1130 \\
1 \\
14 \\
32 \\
47 \\
175 \\
1352\end{array}$ & $\begin{array}{c}3 \pm 3 \\
2 \pm 1 \\
55 \pm 9 \\
5 \pm 2 \\
29 \pm 7 \\
\mathrm{~T} \\
94 \pm 2 \\
\mathrm{~T} \\
2 \pm 1 \\
1 \pm 1 \\
3 \pm 2 \\
3 \pm 1 \\
100\end{array}$ & $\begin{array}{c}6 \pm 2 \\
1 \pm 1 \\
50 \pm 8 \\
7 \pm 2 \\
19 \pm 3 \\
T \\
83 \pm 4 \\
1 \pm 1 \\
12 \pm 7 \\
3 \pm 1 \\
16 \pm 8 \\
1 \pm 1 \\
100\end{array}$ \\
\hline
\end{tabular}

$* \mathrm{~T}=<5 \%$

* Dietary contribution was significantly different $(P<.05)$. 
ported by available production data (Table 1). On the other 3 enclosures browse use by cattle was minor and was not readily observable. The heavier use of browse in enclosure 1 was attributed, in part, to being within $400 \mathrm{~m}$ of a major water source. No significant dietary differences for individual plant species were found between grazed and ungrazed areas because of the high variability of deer diets. However, the effect of cattle grazing did cause a significant $(P<.05)$ shift from the forb-dominated diet selected by mule deer on the ungrazed area to a browse-dominated diet on the grazed area.

In enclosures 2 and 3 cattle removed about $60 \%$ and $45 \%$ of the grass production, respectively (Table 1 ). The only significant differences in deer diets between treatments in enclosures 2 and 3 occurred with 2 highly palatable forb species, goldenrod (Solidago sparsiflora Gray) and knotweed (Polygonum douglasii Greene).

Enclosure 4 contained the lowest production of grass, which led, in part, to the highest utilization level by cattle (84\%). Available production and variety of browse species used by deer was highest in this enclosure, but no significant dietary differences occurred between cattle-grazed and -ungrazed areas.

Over all enclosures deer selected a significantly higher proportion of forbs on areas ungrazed by cattle $(P<.05)$, whereas green grass and browse consistently contributed higher proportions on grazed areas (Table 1). Other browse as listed in Table 1 was unpalatable and highly dominated by big sagebrush (Artemisia tridentata Nutt.) in all enclosures.

Nutritionally, deer diets between cattle-grazed and -ungrazed areas showed few differences (Fig. 2). Crude protein values of deer

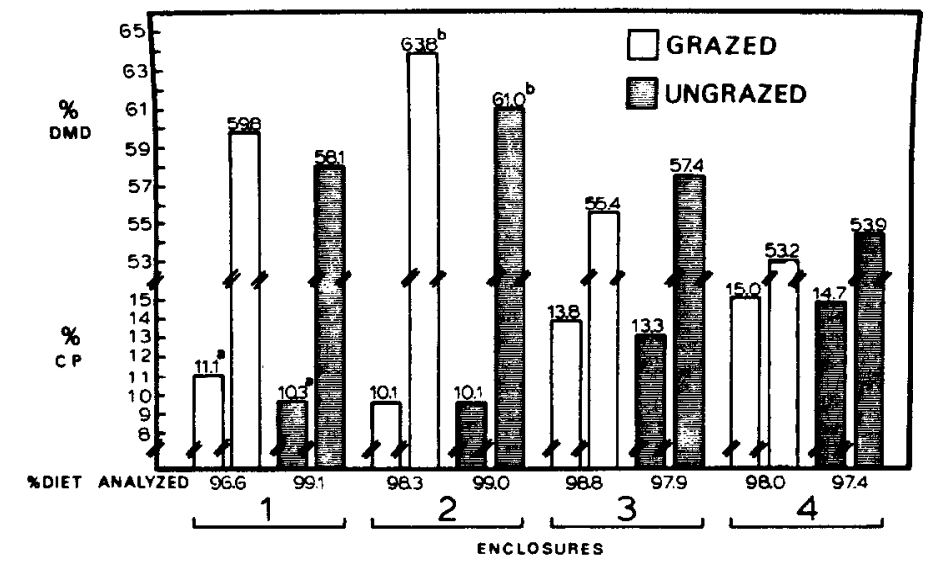

Fig. 2. Weighted \% crude protein (CP) and \% in vitro dry matter digestibility (DMD) from split enclosures-half grazed and half ungrazed by cattle.

diets were slightly and consistently, although not significantly, higher on the cattle-grazed areas, except enclosure 1 where a mean difference of $0.8 \% \mathrm{CP}$ was significant $(P<.05)$. In vitro dry matter digestibility averaged $58.0 \%$ on the grazed areas and $57.6 \%$ on the ungrazed areas. The only significant difference $(P<.05)$ occurred in enclosure 2 where digestibility was over $60 \%$ for both grazed and ungrazed areas.

Upon first exposure to cattle-grazed and -ungrazed areas, individual deer selected forage in areas ungrazed by cattle (Fig. 3). During the initial dietary collection period (0-20 deer-days/ha) over all enclosures deer selected an average of $69.4 \%$ of the total bites in ungrazed areas and differences were significant $(P<.05)$ in all enclosures.

Area selected for grazing when the 4 deer were placed together in the enclosures changed between days (Fig. 4). On the first day (20-40 deer-days/ha) deer spent a significantly $(P<.05)$ higher percentage of time foraging in the cattle-ungrazed areas. Only in enclosure 3, where cattle grazing was lightest, was the difference not significant. In contrast, during the second day (40-60 deer-

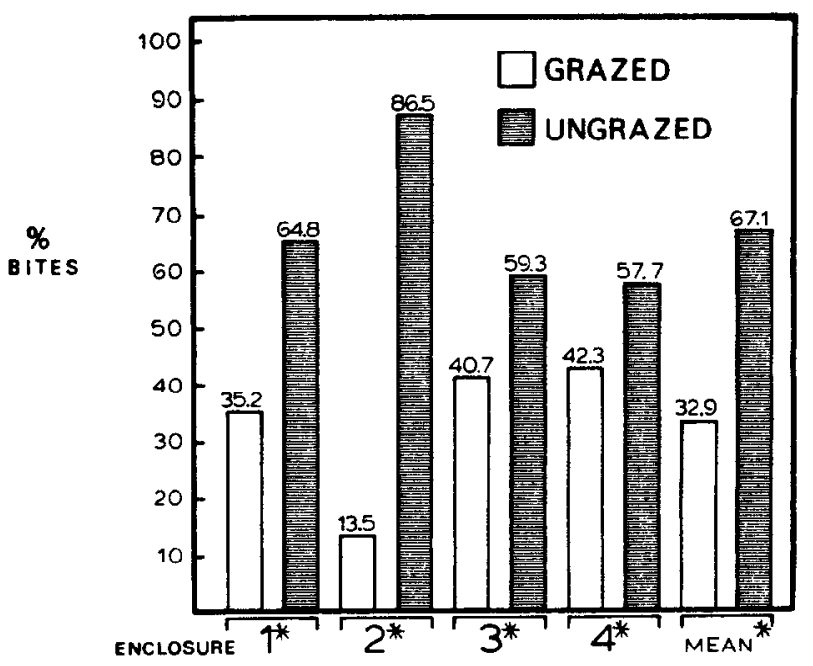

Fig. 3. Percentage of bites selected by mule deer during the initial freeroaming grazing period on split enclosures-half grazed and half ungrazed by cattle.

days/ha) no significant differences were found.

\section{Discussion}

The influence of cattle grazing on mule deer was found to be variable depending on the intensity of cattle grazing and the criteria used to assess deer response. At levels of cattle grazing intensity where the primary impact was on understory vegetation, our data indicated that few individual species were altered in deer dietary composition, although deer diets were somewhat shifted in favor of browse and grass on grazed areas. The shift toward more grass and browse and fewer forbs in deer diets, which was significant only in enclosure 1 and over all enclosures combined, was probably primarily due to a lower abundance of forbs in cattle-grazed areas, and secondarily due to the sparse regrowth of grass. Nonetheless, neither CP nor IVDMD were significantly affected in deer diets.

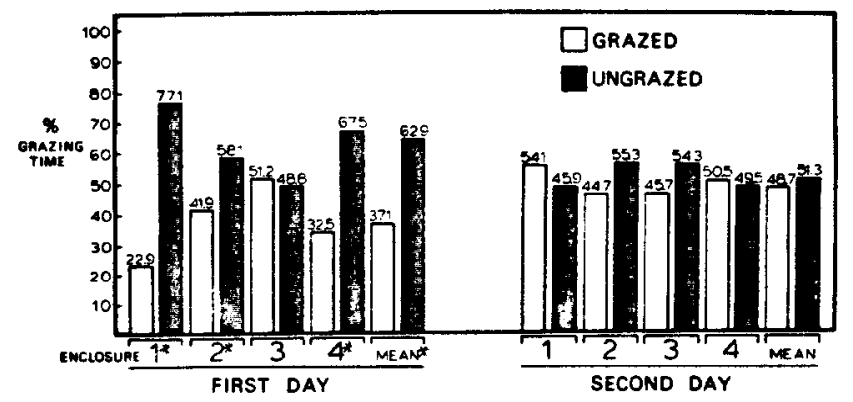

Fig. 4. Percentage of graxing time spent by mule deer on split enclosures half grazed and ungrazed by cattle.

In contrast, deer did select areas ungrazed by cattle during initial foraging and subsequently during the first day of area selection observation. However, with increasing deer use during the second day of observation, selectivity for ungrazed areas was not found in any enclosure. When approximately $\mathbf{4 0}$ deer days/ ha had accumulated, the selectivity for ungrazed areas was eliminated. At the heavier, probably excessive, level of cattle use where all classes of vegetation were significantly impacted, the effects on mule deer diet composition, area selection, and percent dietary $C P$ were significant. Julander (1955) working on a similar nearby range indicated that proper use of grasses by cattle caused little effect on deer, but that over-grazing led to severe competition on the summer 
range.

Since mule deer and cattle diets often overlap by only 1-10\% (Mackie 1981), including ranges similar to the Sheeprock Mountains (Lesperance et al. 1970), and social competition between deer and cattle is minor (Julander 1955, Kramer 1973, Skovlin et al. 1976, Willms et al. 1979), the relatively low level of significant differences due to cattle grazing found in this study is not surprising. Also the high mobility and forage selectivity of unconfined deer would tend to further reduce the effects of cattle grazing on deer diets (Lesperance et al. 1970) in contrast to our study where deer were restricted to small areas.

Parallel to our findings, Willms et al. (1980), using a similar experimental design, reported that deer diets between areas grazed and ungrazed by cattle were generally not different in the Douglas fir zone. They also indicated cattle grazing tended to shift deer diet selection toward heavier use of shrubs, and that with increasing deer use, differences between cattle-grazed and -ungrazed areas decreased. McMahan (1964) similarly found a shift in white-tailed deer diets toward more browse and grass, and less forb use on cattle-grazed areas in Texas.

We conclude the grazing effects of cattle, on mixed browse communities in the Great Basin, on mule deer diets and nutrition in summer are minor when intensity of cattle use is controlled such that cattle primarily use only understory vegetation. However, deer did prefer areas ungrazed by cattle at all levels of cattle grazing intensity studied when deer use was low; this preference was rapidly eliminated as deer use increased.

\section{Literature Cited}

Altmann, J. 1974. Observational study of behavior: sampling methods. Behaviour 47:227-265.

Austin, D.D., P.J. Urness, and L.C. Fierro. 1983. Spring livestock grazing affects crested wheatgrass regrowth and winter use by mule deer. J. Range Manage. 36:589-593.

Austin, D.D., and P.J. Urness. 1985. Values of four plant communities for mule deer on ranges with limited summer habitat. J. Range Manage. 38:167-171.

Brooks, J., and P.J. Urness. 1984. Comparison of in vivo and in vitro digestibility of forage by elk. J. Animal Sci. 58:963-970.

Campbell, E.G., and R.L. Johnson. 1983. Food habits of mountain goats, mule deer, and cattle on Chopaka Mountain, Washington, 1977-1980. J. Range Manage. 36:488-491.

Hansen, R.M., R.C. Clark, and W. Lawhorn. 1977. Foods of wild horses, deer, and cattle in the Douglas Mountain area, Colorado. J. Range Manage. 30:116-118.

Hansen, R.M., and L.D. Reid. 1975. Diet overlap of deer, elk, and cattle in Southern Colorado. J. Range Manage. 28:43-47.

Hubbard, R.E., and R.M. Hansen. 1976. Diets of wild horses, cattle and mule deer in the Piceance Basin, Colorado. J. Range Manage. 29:389-392.
Jensen, C.H., A.D. Smith, and G.W. Scotter. 1972. Guidelines for grazing sheep on rangelands used by big game in winter. J. Range Manage. 25:346-352.

Julander, 0.1955. Deer and cattle relations in Utah. Forest Sci. 1:130-139.

Kramer, A. 1973. Interspecific behavior and dispersion of two sympatric deer specics. J. Wildl. Manage. 37:288-300.

Lesperance, A.L., P.T. Tueller, and V.R. Bohman. 1970. Symposium on pasture methods for maximum production in beef cattle: competitive use of the range resource. J. Animal Sci. 30:115-121.

Longhurst, W.M., G.E. Connolly, B.M. Browning, and E.o. Garton. 1979. Food interrelationships of deer and sheep in parts of Mendocino and Lake Counties, California. Hilgardia 47:191-247.

Mackie, R.J. 1981. Interspecific relationships, p 487-507. In: O.C. Wallmo (ed), Mule and black-tailed deer of North America. Univ. Nebraska Press, Lincoln.

McMahan, C.A. 1964. Comparative food habits of deer and three classes of livestock. J. Wildl. Manage. 29:798-808.

Neal, D.L. 1981. Improvement of Great Basin deer winter range with livestock grazing, p 61-73. In: Proceedings of the Wildlife-Livestock Relationships Symposium. Dep. Wildl. Res. Univ. Idaho, Moscow.

Neff, D.J. 1974. Forage preferences of trained mule deer on the Beaver Creek watersheds. Ariz. Game and Fish Dep. Spec. Rep. No. 4.

Reiner, R.J., and P.J. Urness. 1982. Effects of grazing horses managed as manipulators of big game winter range. J. Range Manage. 35:567-571.

Skovlin, J.M., R.M. Harris, G.S. Strickler, and G.A. Garrison. 1976. Effects of cattle grazing methods on ponderosa pine-bunchgrass range in the Pacific Northwest. USDA Forest Serv. Tech. Bull. 1531.

Smith, A.D. 1949. Effects of mule deer and livestock upon a foothill range in northern Utah. J. Wildl. Manage. 13:421-423.

Smith, A.D., and D.D. Doell. 1968. Guides to allocating forage between cattle and big game on big game winter ranges. Utah State Div. of Fish and Game Pub. 68-11.

Smith, M.A., J.C. Malechek, and K.O. Fulgham. 1979. Forage selection by mule deer on winter range grazed by sheep in spring. J. Range Manage. $32: 40-45$.

Urness, P.J. 1981. Livestock as tools for managing big game winter range in the Intermountain West, p. 20-30. In: Proceedings of the WildlifeLivestock Relationships Symposium. Dep. Wildl. Res. Univ. Idaho, Moscow.

Vavra, M., and F. Sneva. 1978. Seasonal diets of five ungulates grazing the cold desert biome, p. 435-437. In: D.N. Hyder (ed), Proc. Ist Int. Rangeland Congr. Soc. for Range Manage, Denver.

Welch, B.L. 1983. Ability of different rumen innocula to digest range forages. J. Wildl. Manage. 47:873-877.

Willms, W., A. McLean, R. Tucker, and R. Ritcey. 1979. Interactions between mule deer and cattle on big sagebrush range in British Columbia. J. Range Manage. 32:299-304.

Wilms, W., A. McLean, R. Tucker, and R. Ritcey. 1980. Deer and cattle diets on summer range in British Columbia. J. Range Manage. 33:55-59. 